\title{
Thresholds to the Imaginary
}

\author{
Lucy Reynolds
}

mongst the many texts and articles that Maya Deren produced concerning the
processes and properties of film, it is notable that she writes enthusiastically of the
suggestive potential of cinema technology to create effects that could suspend
belief. She even entitled a 1946 magazine article "Magic is New," demonstrating that
she was not shy of using the term "magic" in relation to her practice and proclaiming:
"[W]hat particularly excited me about film was its magic ability to make even the most
imaginative concept seem real."' Surprisingly little has been written about Deren's interest
in film's magical potential. Nor has the natural magic that she conjures been subject to close
critical analysis, either for its formal methods or its effects on the viewer. With the excep-
tion of Lucy Fisher's insightful 2001 comparison to the French filmmaker magician George
Méliès, ${ }^{2}$ Deren's appreciation of film magic has more often been alluded to than explicitly
addressed in film scholarship. Emphasis has tended to be placed on her use of ritual in film
and writing, as the analyses of writers from Annette Michelson to Renata Jackson have
shown. ${ }^{3}$ In what follows here, I argue for the significance that magic plays within Deren's
practice, both as a filmmaker and an advocate-as her early article shows- for the potency
of the cinematic medium as a space for magic.

For me, Deren's creative displacements of time and space share the properties of the "natural magic" first articulated by the sixteenth-century scientist Giovanni Battista della Porta. In his book Magiae Naturalis he describes how, in a portent of cinema, the mechanics of early optical technology associated with the camera obscura and parabolic mirrors could conjure the presence of illusions both terrifying and marvelous from the environment around them. Thus was opened up the potential for optical technology as a tool for suggestive spectacle as well as scientific study, through what Tom Gunning has referred to as the "creation of new relations between the perceiving eye and the power of light."4 If della Porta relied on the technological refraction and distortion of the world around him to create monsters, so Deren took the viewer's belief in the truth of the filmstrip's photographic inscription as a starting point from which belief might be suspended. Through the camera mechanics of slow motion, reverse, and stop-frame, and her precise use of montage, photographic certainties thus coalesce with her deft manipulation of cinematic time and space to create bodies and places that appear to transcend the laws of natural gravity-whether to multiply oneself in Meshes of the Afternoon, to take flight across space in A Study in Choreography for Camera, freeze statue-still in Ritual in Transfigured Time or become a celestial body moving stately among the stars in her last film, The Very Eye of Night. For Deren's enthusiastic writings on the attributes of cinema technology could be seen to share something of della Porta's desire to communicate the unparalleled properties that his optical devices offered, and the illusions they could effect. Her suggestions for how the amateur filmmaker might manipulate filmic time and space employ the simple 
sleights of hand familiar from the films of early cinema masters such as Georges Méliès or Mack Sennett. She explains, for instance, the temporal interpositions of the stop-frame technique with the example of the running figure across the sand dunes in her film At Land: "that the running can be interrupted at any moment, and resumed on the same frame... [A]nd so the girl, who started out so near us, has, in a magic way, become rapidly distant." This is not to suggest that she courted the knowing thrill and delight in illusion which the magician hopes to draw from his audience, and which relies as much on the revelation, and appreciation, of his trickery as it does upon the incredulity it first engendered. As Lucy Fisher rightly asserts when she compares Deren and the film magician George Méliès: "for Méliès, magic is fundamentally a 'trick', for Deren it constitutes access to the 'marvelous."' Thus Deren might be understood as a different kind of showman from either Méliès or forbears like della Porta and the magic lanternist Athanasius Kircher. The key to her difference lies in Fisher's emphasis on the term "access." For the mode of perception which Deren sought from film was not a trick of the eye, but the means to create a threshold to an inner space, where the realms of the imaginary might be shaped into material form. As she put it: "The creative effort should be directed not at making a thing look like itself, but at using the capacity of the camera to make it look like what the audience should feel about it."7

Deren's intent that a thing should "look like what the audience should feel about it" implies a desire for the camera to act as a device for psychic projection, where once familiar objects and situations - a telephone off the hook, a cocktail party-take on strange, often uneasy, dimensions, which prompt associations in the mind of the viewer. Deren's games of defamiliarization can be traced back to the Surrealist's earlier acknowledgement of cinema's inherently transformative "modern magic." For them, as Paul Hammond describes it, film had the power to "confer a dignity and poetic value on common objects, to render them into what Freud called 'thing-representations,' indices of the unconscious." As Hammond suggests, the new significances that cinema afforded to the banal was conferred by its power of focus: "In isolating objects, magnifying them and recombining them in new ways, things were revealed-and reveiled, as [André] Breton demanded-in all their fulsome, hieratic mystery." ${ }^{8}$ Thus, as Louis Aragon would have it: "a bottle that on occasion becomes a weapon, a handkerchief that reveals a crime, a typewriter that's the horizon of a desk."

Deren's own writings also share this recognition of film technology's power of metamorphosis, and appreciation of the unique potential of the medium. Yet, at the same time, she was categorical in distancing her practice from that of the Surrealists. Indeed, as the programme notes that prefaced her early screenings declared:

Under no conditions are these films to be announced or publicized as surrealist or Freaudian [sic ]. This is not only a serious misrepresentation of the films, but also confuses the audience by inspiring a false interpretation of the films according to sustems [sic] to which they bear no relation. The preoccupation with conscious control of form which is involved ... is obviously at variance with the Sur-realist esthetic of spontaneity. ${ }^{10}$

Deren's emphatic disavowal suggests that she perceived a fundamental difference between herself and the Surrealists at the level of control asserted over the construction of the film form, setting her own careful orchestrations of filming and editing in contrast to the chance operations seen to be practised by the latter. However, a shared methodology, and desire to 
access the subconscious, has certainly been identified between Deren and the practices of the Surrealists. Ute Holl observes that: "Deren's cinematic tricks that associate, condense, and displace the visual material actually correspond to what Freud described as the processes of dream work and to what the Surrealists called expressions of the subconscious."11 For Holl, the difference between Deren and the approach of the Surrealists-already hinted at in Deren's programme note refutals - was their belief that these cinematic effects were inherent to the workings of the subconscious, whereas Deren understood them as the result of the artist's own subjective vision and technological manipulations, or as Holl puts it, "consciously applied effort."12

George Amberg's contemporaneous comments illuminate an additional difference of emphasis which might enlighten us further about Deren's view of Surrealism in relation to her practice. For him, the undermining tactics of the Surrealist "shock effect" were designed to "destroy confidence in the validity of the world which they create and frustrate the potential participation of the spectator in it." In contrast, Amberg perceives in Deren's films a "powerfully convincing reality" of overarching and cohesive logic where the images are "chained to each other on the level of emotional, visual and logical implication."13 It is telling that Deren places Amberg's text within her first serious essay on her film method, "Cinema as an Independent Art Form" (1945), for it presages a subject she returned to throughout her writing..$^{14}$ In agreement with Amberg, she saw her films as evincing what she often referred to as a "classical structure," where the disjunctures of time and space explored were less concerned with eliciting visceral reactions in her audiences through a series of shock images, than building a persuasive and all-encompassing world, however strange, into which the viewer is slowly initiated.

Deren may have been understandably defensive that her films were judged in relation to an earlier European avant-garde rather than on their own merit as contemporary works. However, her unfinished first film, Witch's Cradle, further complicates the question by implying an alignment to the very art worlds she dismisses. Set in the Museum of Modern Art's "Art of This Century" galleries, her camera pans over the sculptural works of artists associated with Surrealism, such as Hans Arp and Magritte, as well as other pre-war European artists such as that most iconic figure of the pre-war avant-garde, Marcel Duchamp, depicted tangled within his own string sculpture..$^{15}$ On the other hand, this first foray into film also provides glimpses of the interests in game-play and ritual that would come to inform Deren's later work: for instance, the arcane symbols painted upon the central figure of a young woman, whilst the title of the film alludes to Deren's burgeoning interest in the occult and the supernatural, as well as positing the first of the female protagonists who would dominate her films.

Despite some compelling arguments, it may therefore be more productive to see Deren's practice in relation to the wider discussions of pre-war thinkers contemporary to the Surrealists, who were also engaged in debating the potential, and social, impact of the new medium. For example, in his famous 1936 essay, "The Work of Art in the Age of Mechanical Reproduction,"Walter Benjamin uses the concept of the unconscious to delineate the unique and intrinsically modern mode of perception that cinema opens up to the viewer. Although there is no evidence from Deren's writings that she knew of Benjamin's discussions of cinema, his description of an "optical unconscious" bears relation to Deren's belief that cinema was "the most propitious and appropriate art form for expressing, in 
terms of its own paradoxically intangible reality, the moral and metaphysical concepts of the citizen of the new age." ${ }^{\prime 16}$ Deren's observations, for example, about "The ideas of condensation and of extension, of separateness and of continuity, in which it [film] deals,"17 might also be seen to echo Benjamin's own observations that the "resources of the camera" such as slow motion, close-up and other mechanistic operations opened up in familiar actions and objects an "unconsciously penetrated space" and "different nature."18 Indeed, Benjamin's descriptions bring to mind the opening sequence of Meshes in which the door key that falls from Deren's hand is caught in ominous slow motion and close focus as it bounces down the steps, assuming a significance disproportionate to its size and mundane function.

Deren was certainly aware of other pre-war theories of cinematic perception, and in An Anagram of Ideas on Art, Form and Film, her ambitious 1946 treatise on film theory and aesthetics, she mentions how she had just received the French filmmaker and poet Jean Epstein's book I'Intelligence d'une Machine. Deren clearly felt him a kindred spirit, writing of how the implication of the title, and his "poetic, inspired tone" led her to believe that they shared "a profound respect for the magical complexities of the film instrument."19 No further references to Epstein exist in Deren's writings, but a comparative reading of their theories on cinema reveals a shared recognition of film technology's extra-ordinary abilities, which for Epstein was the "cinematic property of things, a new and exciting form of potential."20 Like Deren, Epstein privileged the potential of time relations in cinema, writing of how the camera was capable of "making immensely more supple the play of temporal perspective."21 However, it is Epstein's notion of photogénie which seems particularly significant to Deren's understanding of cinema technology's power of evocation, or "magical complexities," for he suggests that the camera might open up, not only a new mode of perception to the viewer, but might also expose the very soul, and "inner nature of things." 21 The much debated difference between the Surrealist understanding of cinema and Deren's gains a further difference of emphasis beyond that of Amberg's professed distinctions, when read in relation to Epstein. For the latter argued for the profound potential of cinema to expose the essence of an object or person, rather than simply allow for the surfacing of the subconscious. This comes much closer, I would argue, to Deren's understanding of the alternate, interior worlds which cinema technology could unlock; perceived by Epstein as "untrue to everyday reality just as everyday reality is untrue to the heightened awareness of poetry."22 Deren also writes with admiration in Anagram of the "economy of statement" to be found in Jean Cocteau's film The Blood of a Poet (1930), and later cites his effective use of reverse motion and negative image in Orphée. ${ }^{23}$ Like Deren, Cocteau also conjured spaces of bewitchment by utilizing the simple cinematic trickery beloved by Méliès or Sennet, such as the use of slow, reverse and stop-frame motion to suggest different registers of gravity within a space, or as a means of investing the protagonist with magic powers. These effects often occur once a threshold has been crossed, or a portal opened, such as when Orphée passes through the mirror into Cocteau's shattered underworld, or Deren crawls from beach to rowdy dining table in At Land. Often misleadingly associated with the Surrealists, ${ }^{24}$ Cocteau's interest in the supernatural worlds and beings associated with mythology are well documented in his poetry, artwork and his films. These might be compared with Deren's own fascination with the structures of myth and fable, which was to find its most overt expression in her final film, The Very Eye of Night, in which dancers assume the identity of the mythological figures who populate the night sky as the stars of the 
zodiac. Furthermore, as the occult symbolism in Witch's Cradle already suggests, the notion of myth in Deren's work cannot be disconnected from her understanding of ritual. A dominant theme of her films and wider philosophy, she takes care to explain her understanding of ritual in Anagram, after establishing that her definition looks beyond, yet encompasses, the specific rites and ceremonies with which anthropology associates the term, including "a specific magical purpose." ${ }^{\prime 25}$ Rather, ritual for Deren posits a morally-inflected and collective sense of consciousness, which acknowledges the authority of myth and "man's relationship with deity."26 Much analyzed in relation to her ethnographic practices in Haiti, and in the examination of theoretical texts such as Anagram, as well as through close readings of the film themselves, her notion of ritual remains compelling, yet often elusive-determined by the changing concerns of Deren's art and her interests. ${ }^{27}$ It is as if each of her films explores different ritualized forms: the occult of Witch's Cradle; the game of chess so central to the protagonist's journey in At Land; the social rituals of marriage in Ritual in Transfigured Time; or the trance possessions within which she participated in Haiti. Like Cocteau, several of her films overtly depict a ritualized threshold space requiring certain actions for access: a repeated unlocking of the door to the house in Meshes, a chess piece as a guide in At Land, or the doorways from one dominion into another depicted at the beginning of Ritual in Transfigured Time, with Anaiis Nin as their imposing sentinel. Deren's experiences in Haiti brought into another register her belief in the ritual power of rhythm and movement, which signals less a subjective state of being than a form of collective embodiment, characterized by Moira Sullivan as "the element of a depersonalized individual within the dramatic whole."28 For Deren, this allowed the dancer, or initiate, to become "part of a dynamic whole which, like all such creative relationships, in turn, endows its parts with a measure of its larger meaning." 29

However, it is important to stress that Deren's understanding of ritualized form was intimately connected to film form. For she believed it was through the unique "creative time-space relationships" of cinema technology, that she could most effectively create a sense of the dynamic whole which she sought. Indeed, as Holl argues: "her understanding of'ritualistic'is not a (pseudo) primitive one but refers to the media aspect of art: artforms, as she will further elaborate in Anagram, are historical techniques of transmission that produce reality. ${ }^{\prime \prime 0}$ The social and religious ceremonies which she presents in Ritual in Transfigured Time, for example, reach a level of ritual signification only possible through her manipulations of film technology. Here, film's printing processes effect a transformation at once scientific and alchemical, when Rita Christiani's widow's weeds becomes a bridal gown through the simple action of silver nitrate chemicals reversing positive to negative image. Deren's use of slow-motion and freeze-frame throughout the film brings an intensity to the interactions between the protagonists, exposing the nuances of their encounters as they are frozen into a series of attitudes and postures, as if, in mythological allusion, turned to stone. In the film's most notable use of slow-motion, Deren herself acquires a psychotic, even malevolent, aspect as the muscles of her smiling countenance, filmed in close-up, appear to perceptibly flap and stretch into grotesque form as she turns her head. This unnerving close-up shows the enchantment that she weaves with her film camera is not necessarily of a benign nature, being deeply connected to the rituals and myths of life and death. Holl surmises, Deren's "dangerous yet promising adventures" investigate "archaic and modern ritualistic forms" in order to "extend the visual horizon of perceivable selves." ${ }^{\text {"11 }}$ 
And what better medium to choose for her explorations than a technology that holds the power to breathe life into the inanimate and resurrect what is past? For despite Deren's insistence that the effect of her films springs from her "conscious control" of film form, I would argue that her careful temporal spatial manipulations shape an evocative power already latent in film, the profound role of cinematic time as an agent of resurrection, to summon the once dead into spectral on-screen form. Prefaced by its mirror-faced harbinger, film's powers over life and death resonate in the ambiguous interplay of waking, dreaming and death that repeat themselves throughout Meshes of the Afternoon, and become almost literalized in Rita Christiani's ghostly white form as she appears to rise up through the negative film image at the end of Ritual in Transfigured Time.

Cinema's technological power to raise apparitions returns us firstly to della Porta's natural magic, where incredulity at the effects of his optical devices encouraged people to believe that they saw visions, eliciting a return to the superstitions and irrational beliefs of more archaic times. Laura Mulvey terms this uneasy mixture of wonder, fear and disbelief, where science and superstition collide, "a technological uncanny," where "the most rational mind experiences uncertainty when faced with an illusion that is, if only momentarily, inexplicable."32 Mulvey cites Freud and Wilhem Jentsch's famous texts on the uncanny to make a case for the innately uncanny qualities of film, which, like della Porta's parabolic mirrors, might produce what Freud referred to as "that species of the frightening which goes back to what is once well known and had long been familiar."33 Mulvey suggests that this confusion of technology and science with the supernatural arises in cinema from the "indexical uncanny" of the photographic inscription at the heart of the filmstrip, which carries its own imprint of technologically induced reality and of time arrested. The particular presentiment of death — a sensation which André Bazin referred to as photography's "embalmed" timeis brought into a register of further uncanny dimensions when movement is returned to it by the agency of the film projector, bringing an unnatural veracity to the images on screen. Here, Mulvey notes an enchantment in cinema which goes more profoundly into questions of perception than a sleight of hand, when she writes that: "This is not the mystery of the magic trick but the more disturbing, uncanny sensation of seeing movement fossilized for the first time." ${ }^{\prime 3}$

Cinema's acute sensitivity to the power of passing time, which enables it to conjure life, or imprint death, in the frame, produces a sense of the uncanny that emanates strongly from Deren's films. It is apparent, for instance, in the unheimlich spaces of the house to which she repeatedly returns in Meshes of the Afternoon, their familiar dimensions inexplicably made strange. It also manifests in the deathly significance of the double in her films, most vividly as she multiplies her own self in Meshes to become a coven of four, playing a ritual game with knife and key-familiar objects which themselves assume a talismanic power. Deren conjures these "familiars" (to evoke the word's ritual context) through an experimental application of techniques similar to those used to establish narrative continuities in fiction cinema. Here the eyeline match is applied, not to delineate the space of narrative diegesis, but as a mode of multiplication across spaces, as one Maya turns to look across the sand dunes in At Land to another, who occupies the edge of the table, or struggles through a thicket of leaves. In Ritual this exercise of suture extends to an uncanny shift of identities, where by cutting on the movement of a turn of the head, or the gesture of an outstretched arm, Christiani metamorphoses into Deren. 
Citing Otto Rank's definitive study on the subject, Freud connects the form of the double with: "mirror-images, shadows, guardian spirits, the doctrine of the soul and the fear of death."35 As he asserts, the double was once seen as a magic insurance against death, evident in the effigies and paintings in the tombs of Egyptian kings, the first expression of the "immortal soul." But in another example of the familiar becoming the demonic other, its role is now reversed to signify instead "the uncanny harbinger of death." ${ }^{16}$ In Meshes, the double assumes its most ominous shape, going beyond the role of harbinger to become the instigator of death as she grasps the knife, flinging it through the mirror. However, amongst the many selves pictured, who is guilty of the crime? And who is dead? The double becomes here a means through which an additional layer of ambiguity is added to this already beguiling film. Maureen Turim perceives these multiplications as reflections of the woman's relationship to "the other, to her various selves." This "splitting of the subject" implies the fragmentation of female identity, as well as "a multiplicity of positions, fragmentations, and transformations that appear to be seeking a location in domestic violence. ${ }^{137}$ As a reflection of the trauma of patriarchy, it is a compelling reading, offering the same interpretative power as Lauren Rabinovitz's assertion that Meshes resembles the structure and iconography of film noir, with its portrayals of the powerful and ultimately dangerous female. The materialization of Deren's four counter-selves could be seen to represent the different aspects of her psyche, taking us back to Freud's reading of the uncanny double as a disturbance or disassociative disorder of the ego. Deren's own programme notes for Meshes appear to affirm this reading, when they speak of the film's concern with "the inner realities of an individual and the way in which the sub-conscious will develop, interpret and elaborate an apparently simple and causal occurrence into a critical emotional experience." ${ }^{\prime 38}$

Freud recognizes that, whatever the cause, the pervasive sense of ill ease and foreboding attached to the appearance of the double remains powerful and rooted in very ancient urges, both culturally and in the psychological development of the individual, belonging, as he puts it, to "a primitive phase in our mental development, a phase that we have surmounted."399 Through her elegant sutures on the turn of the eye, Deren is thus able to materialize multiple selves that articulate not only the fragmentation of the female body and identity, nor the workings of the subconscious, but also the more profound and inexplicable fear associated with the "terror" of the double with its uncanny portent of death. ${ }^{40}$

Furthermore, as Freud has pointed out, the sensation of the uncanny hinges on the conflict between belief and doubt, where an object, person or place appears simultaneously familiar and yet somehow awry. He gives special attention to the uneasy perceptual slippage which occurs "when the boundary between fantasy and reality is blurred, when we are faced with the reality of something that we have until now considered imaginary, or when a symbol takes on the full function and significance of what it symbolizes, and so forth." ${ }^{\prime 11}$ Applied to cinema, this effacement occurs when, through the agency of photographic inscription onto celluloid, the imaginary worlds caught in movement on screen appear to take on the guise of the real. Deren would refer to this uncanny dialogue between the real and the illusory as the "controlled accident" when the "innocent arrogance of an objective fact"42 presented by the photographic image might be held in "delicate balance between what is there spontaneously and naturally as evidence of the independent life of actuality, and the persons and activities which are deliberately introduced into the scene."43 
Deren achieves this uncanny through a careful edit on the movement and gesture of the body, which finds its most elegant resolution in A Study for Choreography in Camera. In this short film, the limbs of the dancer Talley Beatty become unnaturally elongated, vaulting impossible distances, through the appearance of a continuous pan on movement which leads the eye seamlessly from forest to mountain, interior to exterior, on the tip of a toe. At the same time, emanating from the body in motion on the film screen-even when it is subordinated to the logical flow of narrative-there is always a whisper of the mechanical presence of the apparatus which is its progenitor, such as the camera and projector which bring animation to what Mulvey terms "an inorganic trace of life." ${ }^{\text {"44 }}$ As Mulvey's contradiction implies, cinematic movement produces a doubled and paradoxical experience of the uncanny, where the spectral inscription of the body that was once alive in front of the camera merges with the technological bodies of the machines that capture and regenerate it as a projected cinematic illusion. Mulvey relates this uncanny motion to "the uncanny of mechanized human movement" ${ }^{\prime 45}$ and the automata that both Freud and Jentsch refer to in their studies of the uncanny, whose jerky movements approximate life, whilst also betraying their mechanical origins. She cites Benjamin's eloquent observation of Chaplin, the avant-garde's epitome of cinema's mechanical modernity, producing "the same jerky succession of tiny movements, which applies the law of filmic sequence to that of human motorics."46

Whereas Chaplin's exaggerated jerky movements might be seen as an overdetermined embodiment of cinematic technology, the fluid gestures of Beatty, Christiani, or Deren herself, as I have already argued, function to suture disparate spaces, creating the logic of a "relativistic universe" through a "purely cinematic coherence and integrity." ${ }^{\text {"77 }}$ This is the uncanny propagated by the unique conditions that Deren recognized in the film medium, where the body moves to the technological rhythms of temporal spatial manipulation, not the syncopations of the cinematic apparatus. If Benjamin recognized in Chaplin's step the sequential movements of the film strip through the projector, so we might recognize in Deren's moving bodies the rhythms of her edit and her manipulations of cinematic time and space. Therefore, rather than Chaplin's comic echo of automation, the movements of Deren's protagonists reveal their technological origins through the "cinematic coherence" of slow motion, the freeze-frame and the body sent in motion backwards as well as forward. Their movements describe worlds working to a stranger gravity than the machine: a somnambulist rhythm that evokes the spectral and explains why the notion of trance has so often been attached to Deren's films.

Yet whilst the movements of Beatty, Christiani and others act as points of juncture across filmic space, at the same time their bodies bear the scar of this celluloid severancean injury of the cut sustained beneath their seamless act of suture across space, which accentuates the inhuman uncanny of the filmic body that animates, while it destroys, their on-screen semblance. In this sense, Deren's films resonate with an uncanny consciously conjured as a ritual magic from the agencies of the film form. Writing in 1946 about making At Land, she describes how she was "anxious to develop the idea of cinematic magic in terms of space and time."48 This magic is at work throughout her films, and the beguiling worlds that she creates. As I have argued, more sorcerer than showman, Deren summons magic that does not intend to delight through illusion, nor to deploy the Surrealist tactics of humor and shock, but to offer a darker and often difficult passage into the more profound questions of the rituals of life and death. 


\section{References}

Aragon, Louis. "On Décor" (1917). In The Shadow and Its Shadow: Surrealist Writing on the Cinema, edited by Paul Hammond, 55-59. Polygon: Edinburgh, 1991.

Benjamin, Walter. "The Work of Art in the Age of Mechanical Reproduction" (1936). In Walter Benjamin: Illuminations, edited by Hannah Arendt, 217-251. New York: Schocken Books, 1969.

Deren, Maya. An Anagram of Ideas on Art, Form and Film. In Essential Deren: Collected Writings on Film by Maya Deren, edited by Bruce R. McPherson, 35-109. Kingston, New York: Documentext, 2005.

. "Cinema as an Independent Art Form." In Essential Deren: Collected Writings on Film by Maya Deren, edited by Bruce R. McPherson, 245-247. Kingston, New York: Documentext, 2005.

."Magic is New." In Essential Deren: Collected Writings on Film by Maya Deren, edited by Bruce R. McPherson, 197-206. Kingston, New York: Documentext, 2005.

Epstein, Jean. "On Certain Characteristics of Photogénie" (1923). In "Bonjour cinéma and Other Writings," translated by Tom Milne, 23. Afterimage 10 (1981).

."Magnification and Other Writings."Translated by Stuart Liebman. October 3 (Spring, 1977): 9-25.

Fisher, Lucy. "The Eye for Magic." In Maya Deren and the American Avant-Garde, edited by Bill Nicols, 185-204.

Berkeley: University of California Press, 2001.

Freud, Sigmund. The Uncanny (1919). Translated by David McLintock. London: Penguin Books, 2003.

Hammond, Paul, ed. The Shadow and Its Shadow: Surrealist Writing on the Cinema. Polygon: Edinburgh, 1991.

Holl, Ute. "Moving the Dancers'Souls." In Maya Deren and the American Avant-Garde, edited by Bill Nicols, 151-177.

Berkeley: University of California Press, 2001.

Mannoni, Laurent. The Great Art of Light and Shadow: Archaeology of the Cinema. Exeter: University of Exeter, 2000.

Michelson, Annette. "Poetic and Savage Thought: About Anagram," In Maya Deren and the American Avant-Garde, edited by Bill Nicols, 21-45. Berkeley: University of California Press, 2001.

Mulvey, Laura. Death 24 X a Second. London: Reaktion Books, 2006.

Rees, A.L. A History of Experimental Film and Video. London: BFI, 1999.

Soussloff, Catherine. In Maya Deren and the American Avant-Garde, edited by Bill Nicols, 105-129. Berkeley:

University of California Press, 2001.

Sullivan, Moira. "Deren's Ethnographic Representation of Haiti." In Maya Deren and the American Avant-Garde, edited by Bill Nicols, 207-234. Berkeley: University of California Press, 2001.

Turim, Maureen. "The Ethics of Form." In Maya Deren and the American Avant-Garde, edited by Bill Nicols, 77-102. Berkeley: University of California Press, 2001.

\section{Notes}

1. Deren, "Magic is New," 202.

2. Fisher, "The Eye for Magic."

3. See, for example, Ute Holl, "Moving the Dancers'Souls"; Annette Michelson, "Poetics and Savage Thought"; Renata Jackson, "The Modernist Poetics of Maya Deren"; and Annette Michelson, "On Reading Deren's Notebook."

4. Mannoni, The Great Art, xxii.

5. Deren, "Creating Movies," 137.

6. Fisher," The Eye for Magic," 187.

7. Deren, "Magic is New," 202.

8. Hammond, The Shadow and Its Shadow, 8.

9. Aragon, "On Décor," 57.

10. Deren, qtd. in Rabinovitz, Points of Resistance, 68.

11. Holl, "Moving the Dancers'Souls," 163.

12. Ibid.

13. Qtd. in Soussloff,"Maya Deren Herself," 118.

14. See, for instance, "Creating Movies in a New Dimension: Time" (1946), which she ends with the advice: "But remember - whatever the technique, it must serve the form as a whole, it must be appropriate to the theme 
and to the logic of its development, rather than a display of method designed to impress other movie makers." In Bruce R. McPherson (ed), Essential Deren, 138.

15. Deren wrote of her admiration for Duchamp's film Anemic Cinema in An Anagram of Ideas on Art, Form and Film. See McPherson, 98-99.

16. Deren, "Cinematography: The Creative Use of Reality," 127.

17. Ibid., 126.

18. Benjamin, "The Work of Art," 237.

19. Deren, An Anagram, 102.

20. Epstein, "On Certain Characteristics of Photogénie," in Bonjour Cinema and Other Writings, trans. Tom Milne, 21.

21. Epstein, "Magnification and Other Writings," 9

22. Epstein, "On Certain Characteristics of Photogénie," 23.

23. Ibid.

24. Cocteau and the Surrealists were contemporaries in Paris in the pre-war period but perceived their practices as very different. As A.L Rees asserts, Cocteau was "scathingly attacked by the 'official surrealists in his own time."' Rees goes on to assert that his form of "classicist'return to order"' could be more firmly linked to the work of Georges Franju and post-war French Art Cinema, and credits Cocteau with inaugurating the avant-garde film genre of the psychodrama with which Deren is so often associated. See A History of Experimental Film and Video, 47.

25. See Deren's "Cinematography: The Creative Use of Reality, in McPherson, 121.

26. Deren, An Anagram, 57.

27. Ibid., 58.

28. For more in-depth discussions of Deren's use of ritual see Moira Sullivan, "Deren's Ethnographic Representation of Haiti," 207-234; and Annette Michelson, "Poetic and Savage Thought: About Anagram," 21-45. Both in Nicols, Bill (ed), Maya Deren and the American Avant-Garde.

29. Sullivan, "'Deren's Ethnographic Representation,"' 209.

30. Maya Deren, An Anagram, 58-9.

31. Holl, "Moving the Dancers'Souls," 167-168.

32. Ibid, 171

33. Mulvey, Death $24 x$ a Second, 42.

34. Freud, The Uncanny, 124.

35. Mulvey, Death $24 x$ a Second, 36.

36. Freud, The Uncanny, 142.

37. Ibid.

38. Turim, "The Ethics of Form," 90.

39. Deren, "Cinema as an Independent Art Form," 246.

40. Freud, The Uncanny, 143.

41. It could also be argued that Freud's implication of the double as a folk memory, or product of a cultural consciousness, could also be seen as the point at which the notion of the uncanny touches on Deren's articulation of ritual. She writes in Anagram of how the "deep recesses of our cultural memory release a procession of indistinct figures wearing the masks of Africa, or the Orient, the hoods of the chorus, or the innocence of the child-virgin ... the faces always concealed, or veiled by stylization-moving in formal patterns of ritual and destiny" (55). For Deren, the ritualistic form revealed in these patterns of societal initiation-from song to procession, which "exist simultaneously in unrelated cultures" — were of great importance, revealing "the moral problems which have been the concern of man's relationship with deity, and the evidence of that privileged communication" (58).

42. Freud, The Uncanny, 150.

43. Deren, "Cinematography: The Creative Use of Reality," 117.

44. Ibid., 118.

45. Mulvey, Death 24X a Second, 175.

46. Ibid.

47. Ibid., 178.

48. Deren, "Magic is New," 205. 